\title{
Les difficultés d'accès au savoir d'autrui
}

\author{
Marie-Noëlle Chamoux
}

\section{OpenEdition}

Journals

Édition électronique

URL : https://journals.openedition.org/tc/456

DOI : $10.4000 /$ tc. 456

ISSN : 1952-420X

\section{Éditeur}

Éditions de l'EHESS

\section{Édition imprimée}

Date de publication : 1 novembre 1997

ISSN : 0248-6016

\section{Référence électronique}

Marie-Noëlle Chamoux, «Les difficultés d'accès au savoir d'autrui », Techniques \& Culture [En ligne], 28 1997, mis en ligne le 28 octobre 2005, consulté le 29 septembre 2022. URL : http:// journals.openedition.org/tc/456 ; DOI : https://doi.org/10.4000/tc.456

Ce document a été généré automatiquement le 29 septembre 2022.

Tous droits réservés 


\section{Les difficultés d'accès au savoir d'autrui}

Marie-Noëlle Chamoux 